\title{
Extending the Planting Period of Container Grown Oriental Spruce (Picea orientalis L. Link.) Seedlings into Summer
}

\author{
Zafer OLMEZ ${ }^{1}$, Ergun SUNER ${ }^{2}$ \\ 'Artvin Coruh University, Faculty of Forestry, 08000,Artvin,Turkey; zaferolmez@yahoo.com \\ ${ }^{2}$ Artvin Regional Directorate of Forestry, 08000, Artvin, Turkey
}

\begin{abstract}
This study was carried out to determine the effects of different planting time from June to October on survival, height growth and root collar diameter of the Picea orientalis L. Link. seedlings and to investigate how to extend the planting period in Artvin, Turkey. In general, autumn and spring plantings are the most preferable methods for the oriental spruce reforestations. The nursery where the oriental spruce seedlings were propagated is near the sea level while afforestation areas are between $1200 \mathrm{~m}$ and $1800 \mathrm{~m}$ altitudes, and there is not a cold storage possibility in the nursery to store seedlings until planting time. When the seedlings have bud burst in the nursery, there is snow on the reforestation sites in the spring season, and while the seedlings are growing actively in the nursery it can snow early on the plantation areas, causing planting difficulties. Thus, to overcome this issue, extending the planting period of the oriental spruce can be a solution in the region. To evaluate the possibilities to extend the planting period, the experiment was established using actively growing and dormant seedlings in 2007. The container seedlings were planted regularly at the end of June (cold stored and actively growing seedlings), July (actively growing), August (actively growing) and October (dormant). The statistical approach was a randomized complete block design with three replications and 30 seedlings were planted for each replication. The height growth, root collar diameter and survival rate of the seedlings were defined during four growing seasons. The survival of actively growing seedlings planted at the end of July (84.4\%) and August (91.1\%) did not differ planting date from the end of October (92.2\%) after the fourth growing period, in 2010. The seedlings which were planted at the end of June both cold stored (66.7\%) and actively growing (70.0\%) had the lowest survival rates. The highest seedling height $(39.4 \mathrm{~cm})$ was obtained from the seedlings planted at the end of August. The results showed that with actively growing seedlings, the planting period can be extended from late July to late August without increasing mortality.
\end{abstract}

Keywords: extending, oriental spruce, Picea orientalis, planting period, survival

\section{Introduction}

Oriental spruce (Picea orientalis L. Link.), both ecologically and economically, is one the most important tree species with 297400 ha natural distribution area $(1.4 \%$ of the whole forest area) in Turkey (Anonymous, 2006). There is about 160000 ha oriental spruce forest in Artvin alone and this equals to $41.5 \%$ of whole forest area in Artvin region. However, $31.6 \%$ of the whole oriental spruce forests in Artvin is classified as unproductive and considered necessary to be planted immediately (Albayrak et al., 2005). Moreover, it is impossible to regenerate these unproductive forests via natural regeneration methods due to lack of seed trees. There is also an intensive bark beetle damage caused mainly by Dendroctonus micans (Kug.) and Ips typographus (L.) in the oriental spruce forests in 1990s and 2000s, resulting cutting of a lot of trees and therefore degrading natural regeneration conditions (Eroğlu et al., 2005; Sunar Erbek et al., 2005; Sariyildiz et al., 2008).

Planting in Turkey has traditionally been conducted in the spring, autumn and winter. In general, autumn planting is considered the best planting period for oriental spruce seedlings in the Northeastern part of Turkey (Saatçioğlu, 1970; Yahyaoğlu and Ölmez, 2006). While $2+2$ or $2+3$-year old bare rooted oriental spruce seedlings were used in reforestation efforts until $1990 \mathrm{~s}, 2+0$ container seedlings have been planted after mid-1990s (Ayan et al., 2005; Ölmez et al., 2010).

There are limited studies on extending planting period using containerized seedlings of any forest tree species in Turkey. However, it is shown that the planting period can be extended from spring to summer when container seedlings are actively growing (Luoranen et al., 2005). Helenius et al. (2005) and Luoranen et al. (2006) implied that actively growing Picea abies L. container seedlings can be planted in early summer and these seedlings grow better than seedlings planted in autumn. Previous studies showed that it was possible to expand the planting period for container seedlings of some coniferous species such as Picea glauca, Picea engelmannii, Picea abies, Picea orientalis, Pinus sylvestris, Pinus nigra, Larix decidua from mid-June to end of August (Hanak, 1987; Malinauskas and Sukhots- 
kas, 1996; Orlic et al., 2000; Grossnickle and Folk, 2003; Barzdajn, 2006; Tan et al., 2008; Ölmez et al., 2010). In Canada, summer planting trials with Picea glauca, Picea sitchensis, Picea engelmannii and Pinus condorta seedlings were applied for several years (Revel et al., 1990; Grossnicklle and Folk, 2003; Anonymous, 2010).

The issue of planting period is also common in the Northeastern Black Sea Region of Turkey since the nurseries producing $P$. orientalis container seedlings are located near the sea level while the afforestation areas are usually in higher elevations (between $1200 \mathrm{~m}$ and $1800 \mathrm{~m}$ ) with mountainous and steep terrain. Therefore, when the seedlings have bud burst in the nursery, there is snow on the afforestation sites in the spring season and while the seedlings are growing actively in the nursery it can snow early on the plantation areas, causing planting difficulties. Also, it is not possible to store the seedlings in a nursery because there are not cold storage equipments installed in the nurseries growing oriental spruce seedlings in Turkey. Thus, to overcome this issue, extending the planting period of the oriental spruce can be a solution in the region.

The aim of this present study was to investigate the possibility of extending the planting period of oriental spruce container seedlings from end of June to end of October. Both actively growing and dormant seedlings were planted and the survival and growth of the seedlings were defined during 4 years after planting.

\section{Materials and methods}

Container grown oriental spruce (Picea orientalis L. Link.) seedlings were planted in a research area (latitude: $41^{\circ} 08^{\prime} 55^{\prime \prime} \mathrm{N}$, longitude: $41^{\circ} 46^{\prime} 15^{\prime \prime} \mathrm{E}$, altitude: $1650 \mathrm{~m}$ ) adjacent to natural oriental spruce forests in Artvin region located in the North-Eastern part of Turkey. The seedlings used in the study were grown at the Of Nursery (altitude of $10 \mathrm{~m}$ above sea level) in Trabzon.

The seedlings were planted at the end of June, July, August and October (2007), respectively, in order to ensure that all the seedlings are 3-years old at the end of the first growing season of 2007 (Tab. 1). The experimental design was a randomized complete block design with three replications and 30 seedlings were planted for each replication. The heights and root collar diameters of the seedlings were measured from ground level to the top of seedlings at planting and at the end of each growing season. Each autumn the survival of the seedlings was determined for 4 years. The following 5 different planting dates were applied to determine their effects on survival, height and root collar diameter of the seedlings (Tab. 1)

The weather conditions of Artvin taken from the nearest meteorology station to study area were given in Tab. 2 and the interpolated mean air temperatures $\left({ }^{\circ} \mathrm{C}\right)$ estimated for the study area were given in Tab. 3. Also, the interpolated annual precipitation value according to Schreiber

Tab. 1. The planting time, seedling age and dormancy situation of the container grown oriental spruce seedlings (in 2007)

\begin{tabular}{ccc}
\hline Planting Time & Seedling Age & Dormancy Situation \\
\hline Late June & $2+0$ & Dormant, cold stored at $\pm 4^{\circ} \mathrm{C}$ from February until planting in the laboratory \\
Late June & $2 \frac{1}{2}+0$ & Actively growing \\
Late July & $2 \frac{1}{2}+0$ & Actively growing \\
Late August & $2 \frac{1}{2}+0$ & Actively growing \\
Late October (Control) & $3+0$ & Dormant \\
\hline
\end{tabular}

Tab. 2. Meteorological parameters for Artvin region (Anonymous 1990)*

\begin{tabular}{|c|c|c|c|c|c|c|c|c|c|c|c|c|c|}
\hline \multirow[t]{2}{*}{ Parameters } & \multicolumn{12}{|c|}{ Months } & \multirow[t]{2}{*}{ Annual } \\
\hline & $\mathrm{I}$ & II & III & IV & $\mathrm{V}$ & VI & VII & VIII & IX & $\mathrm{X}$ & $\mathrm{XI}$ & XII & \\
\hline Mean Temp. $\left({ }^{\circ} \mathrm{C}\right)$ & 2.7 & 3.8 & 7.1 & 12.0 & 15.9 & 18.6 & 20.5 & 20.6 & 17.9 & 13.8 & 9.2 & 4.6 & 12.2 \\
\hline Max. Mean Temp. $\left({ }^{\circ} \mathrm{C}\right)$ & 6.2 & 8.2 & 12.4 & 18.0 & 22.0 & 24.2 & 25.5 & 25.9 & 23.7 & 19.5 & 13.6 & 7.9 & 17.3 \\
\hline Min. Mean Temp. $\left({ }^{\circ} \mathrm{C}\right)$ & -0.4 & 0.3 & 2.8 & 7.2 & 11.1 & 14.0 & 16.5 & 16.6 & 13.8 & 9.8 & 5.8 & 1.7 & 8.3 \\
\hline Precipitation (mm) & 85.1 & 71.4 & 55.6 & 53.1 & 50.3 & 46.8 & 27.0 & 25.8 & 35.1 & 55.6 & 70.0 & 87.1 & 662.9 \\
\hline Humidity (\%) & 64 & 64 & 62 & 61 & 65 & 68 & 72 & 71 & 70 & 68 & 65 & 65 & 66 \\
\hline
\end{tabular}

* Observation period: Between 1932 and 1990, altitude: $628 \mathrm{~m}$

Tab. 3. Interpolated mean temperatures $\left({ }^{\circ} \mathrm{C}\right)$ according to Artvin Meteorology Station for the research area

\begin{tabular}{cccccccccccccc}
\hline Parameters & \multicolumn{1}{c}{ Months } & \multicolumn{4}{c}{ Annual } \\
\hline & I & II & III & IV & V & VI & VII & VIII & IX & X & XI & XII & \\
\hline Mean Temp. $\left({ }^{\circ} \mathrm{C}\right)$ & -8.2 & -5.7 & -1.1 & 4.5 & 9.2 & 15.1 & 17.1 & 16.8 & 12.5 & 7.5 & 1.8 & -3.8 & 5.5 \\
Max. Mean Temp. $\left({ }^{\circ} \mathrm{C}\right)$ & -3.2 & -0.7 & 3.9 & 9.5 & 14.2 & 20.1 & 22.1 & 21.8 & 17.5 & 12.5 & 6.8 & 1.2 & 10.5 \\
\hline
\end{tabular}


294

Formula (Çepel, 1995) was found to be $1214 \mathrm{~mm}$ for the research area.

Data from the experiments were analyzed using the SPSS 11.5 for Windows statistical software. The ANOVA and Duncan tests were used to compare treatment groups to find out whether they showed any statistically significant differences with significance level $(\alpha)$ set at 0.05 .

\section{Results and discussion}

Four years after planting, the survival of seedlings varied considerably and the results indicated that the planting date had an impact on this variation. After the fourth growing season (2010 estimations), analyses showed that the best survival rates were obtained from the seedlings planted end of July (84.4\%), August (91.1\%) and October (92.2\%). In addition, there were not any differences in survival rates of actively growing seedlings between the July and August plantings and with the survival rate of dormant seedlings planted at the end of October (control) as well. The results showed that actively growing seedlings planted at the end of July and August had the similar survival compared to seedlings planted in autumn (late October) (Tab. 4). Eyüboğlu and Atasoy (1984) tried late summer plantings using bare rooted oriental spruce seedlings in the Northeastern part of Turkey and found $74 \%$ survival rate. They suggested this method for soils with high moisture and for sites with low radiation. Revel et al. (1990) also studied on summer plantings of Picea abies in order to extend planting period as an alternative to spring and fall plantings and found $78 \%$ average survival rate.

It can also be said that the seedlings planted actively growing in July and August had better survival rates over the dormant seedlings that cold stored until planting in June. On the other hand, both actively growing and dormant seedlings planted at the end of June had higher mortality than other planting periods at the end of the fourth growing season (Tab. 4).

In the first growing period, only the seedlings cold stored at $\pm 4^{\circ} \mathrm{C}$ from February until planting at the end of June had a bud burst and a height growth while the seedlings planted at the end of June, July, August and October did not have any bud burst or height growth. Because of the fact that the actively growing seedlings planted late June did not have a height growth in the first growing season, the mean height $(16.0 \mathrm{~cm})$ and root collar diameter $(4.24 \mathrm{~mm})$ of these seedlings $(16.0 \mathrm{~cm})$ were shorter than the height $(16.4 \mathrm{~cm})$ and root collar diameter $(4.29 \mathrm{~mm})$ of the cold stored seedlings planted late June (Tab. 4). Grossnickle and Folk (2003) stated that the spring-plant stocktype of Picea glauca and Picea engelmannii had both shoot and root growth, while the summer-plant seedlings only root growth during the first growing season on a reforestation site. Luoranen et al. (2006) reported that the seedlings planted before mid-August grew only a few centimeters after planting, while the nursery seedlings grew
Tab. 4. Results of statistical analyses showing the relationship of the survival rates $(\mathrm{S})$, seedling heights $(\mathrm{H})$ and root collar diameters (RCD) among different planting dates (Means in column with the same letter are not significantly different at $\alpha=0.05)$

\begin{tabular}{|c|c|c|c|c|c|c|}
\hline Experiments & F-Ratio & $\begin{array}{c}S \\
(\%)\end{array}$ & F-Ratio & $\begin{array}{c}\mathrm{H} \\
(\mathrm{cm})\end{array}$ & F-Ratio & $\begin{array}{l}\text { RCD } \\
(\mathrm{mm}) \\
\end{array}$ \\
\hline \multicolumn{7}{|c|}{2007} \\
\hline $\begin{array}{c}\text { End of June } \\
\text { (actively growing) }\end{array}$ & \multirow{5}{*}{$12.768^{*}$} & $73.3 \mathrm{a}$ & \multirow{4}{*}{$55.537^{*}$} & $16.0 \mathrm{~b}$ & \multirow{5}{*}{$51.115^{*}$} & $4.24 \mathrm{a}$ \\
\hline $\begin{array}{l}\text { End of June (cold } \\
\text { stored, dormant) }\end{array}$ & & $78.9 \mathrm{ab}$ & & $16.4 b$ & & $4.29 a$ \\
\hline $\begin{array}{c}\text { End of July } \\
\text { (actively growing) }\end{array}$ & & $88.9 \mathrm{bc}$ & & $14.7 \mathrm{a}$ & & $4.21 \mathrm{a}$ \\
\hline $\begin{array}{c}\text { End of August } \\
\text { (actively growing) }\end{array}$ & & $96.7 \mathrm{~cd}$ & & $16.6 b$ & & $4.24 \mathrm{a}$ \\
\hline $\begin{array}{c}\text { End of October } \\
\text { (dormant) }\end{array}$ & & $100.0 \mathrm{~d}$ & & $19.4 \mathrm{c}$ & & $5.35 b$ \\
\hline \multicolumn{7}{|c|}{2008} \\
\hline $\begin{array}{l}\text { End of June (cold } \\
\text { stored, dormant) }\end{array}$ & \multirow{5}{*}{$15.250^{*}$} & $71.1 \mathrm{a}$ & \multirow{5}{*}{$16.755^{*}$} & $18.6 \mathrm{a}$ & \multirow{5}{*}{$7.002^{*}$} & $6.53 b$ \\
\hline $\begin{array}{c}\text { End of June } \\
\text { (actively growing) }\end{array}$ & & $71.1 \mathrm{a}$ & & $22.9 \mathrm{bc}$ & & $6.91 \mathrm{c}$ \\
\hline $\begin{array}{c}\text { End of July } \\
\text { (actively growing) }\end{array}$ & & $87.8 \mathrm{~b}$ & & $21.4 b$ & & $6.62 \mathrm{bc}$ \\
\hline $\begin{array}{c}\text { End of August } \\
\text { (actively growing) }\end{array}$ & & $96.7 b$ & & $23.4 \mathrm{~cd}$ & & $6.06 \mathrm{a}$ \\
\hline $\begin{array}{c}\text { End of October } \\
\text { (dormant) }\end{array}$ & & $97.8 \mathrm{~b}$ & & $24.7 \mathrm{~d}$ & & $6.50 \mathrm{~b}$ \\
\hline \multicolumn{7}{|c|}{2009} \\
\hline $\begin{array}{l}\text { End of June (cold } \\
\text { stored, dormant) }\end{array}$ & \multirow{5}{*}{$15.516^{*}$} & $68.9 \mathrm{a}$ & \multirow{5}{*}{$6.853^{*}$} & $25.0 \mathrm{a}$ & \multirow{5}{*}{$5.410^{*}$} & $8.05 \mathrm{a}$ \\
\hline $\begin{array}{c}\text { End of June } \\
\text { (actively growing) }\end{array}$ & & $70.0 \mathrm{a}$ & & $29.1 \mathrm{a}$ & & $8.60 \mathrm{~b}$ \\
\hline $\begin{array}{c}\text { End of July } \\
\text { (actively growing) }\end{array}$ & & $87.8 \mathrm{~b}$ & & $27.7 \mathrm{bc}$ & & $8.53 \mathrm{~b}$ \\
\hline $\begin{array}{c}\text { End of August } \\
\text { (actively growing) }\end{array}$ & & $91.1 \mathrm{~b}$ & & $28.9 \mathrm{c}$ & & $7.71 \mathrm{a}$ \\
\hline $\begin{array}{c}\text { End of October } \\
\text { (dormant) }\end{array}$ & & $95.6 \mathrm{~b}$ & & $26.8 b$ & & $8.07 \mathrm{a}$ \\
\hline \multicolumn{7}{|c|}{2010} \\
\hline $\begin{array}{l}\text { End of June (cold } \\
\text { stored, dormant) }\end{array}$ & & $66.7 \mathrm{a}$ & & $33.4 \mathrm{a}$ & & 10.01 \\
\hline $\begin{array}{c}\text { End of June } \\
\text { (actively growing) }\end{array}$ & $9.104^{*}$ & $70.0 \mathrm{a}$ & $5.614^{*}$ & $36.8 b$ & $1.722^{\mathrm{NS}}$ & 10.56 \\
\hline $\begin{array}{c}\text { End of July } \\
\text { (actively growing) }\end{array}$ & & $84.4 \mathrm{~b}$ & & $36.1 \mathrm{~b}$ & & 10.99 \\
\hline $\begin{array}{c}\text { End of August } \\
\text { (actively growing) }\end{array}$ & & $91.1 \mathrm{~b}$ & & $39.4 \mathrm{c}$ & & 10.71 \\
\hline $\begin{array}{c}\text { End of October } \\
\text { (dormant) }\end{array}$ & & $92.2 \mathrm{~b}$ & & $36.3 b$ & & 10.81 \\
\hline
\end{tabular}

${ }^{*}$ Planting dates, significantly different at $\alpha=0.05$, NS: Not significant.

better. Similarly, out of all the nursery seedlings used in this study, while the seedlings planted at the end of October had $19.4 \mathrm{~cm}$ of mean height, the mean heights of the seedlings planted in June, July and August varied between $14.7 \mathrm{~cm}$ and $16.6 \mathrm{~cm}$ after the first growing season. How- 


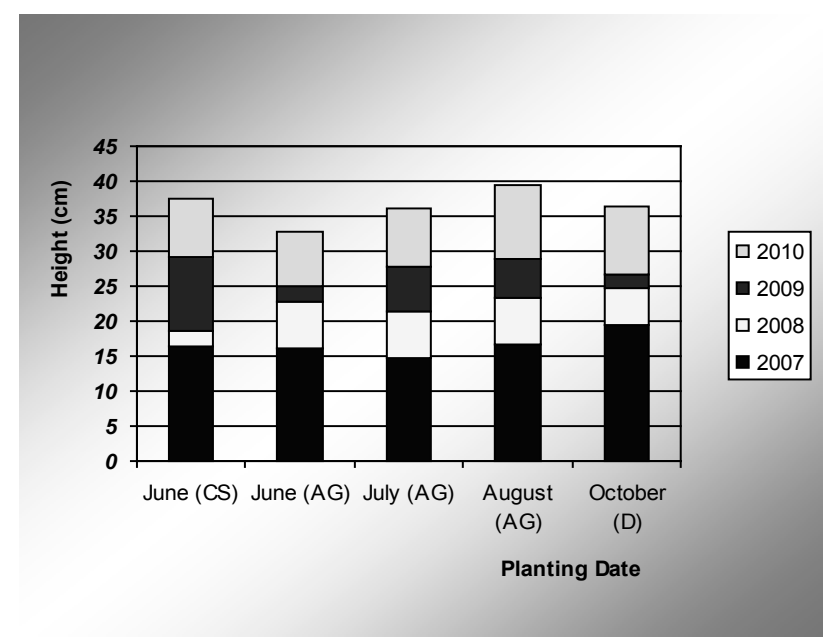

Fig. 1. The height growth of oriental spruce seedlings from 2007 to 2010 (CS: Cold stored, AG: Actively Growing, D: Dormant)

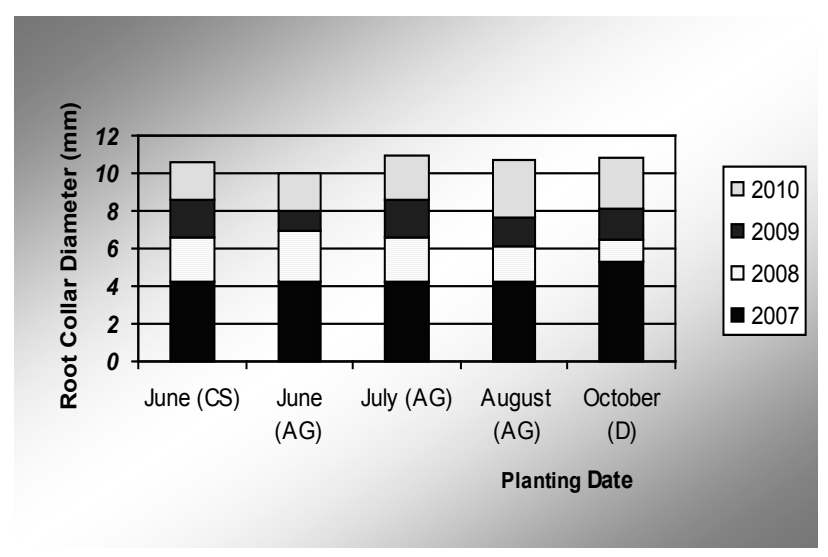

Fig. 2. The root collar diameter growth of oriental spruce seedlings from 2007 to 2010 (CS: Cold stored, AG: Actively Growing, D: Dormant)

ever, four years later, the seedlings planted at the end of August were taller $(39.4 \mathrm{~cm})$ than other plantings (Tab. 4, Fig. 1).

At the end of third growing season, the highest root collar diameters were obtained from the seedlings planted at the end of June (dormant) and July, $8.60 \mathrm{~mm}$ and 8.53 $\mathrm{mm}$, respectively. However, at the end of fourth growing season there were not any significant differences for root collar diameters between planting dates (Tab. 4, Fig. 2).

According to our results, field performance of dormant and actively growing oriental spruce seedlings planted at the end of July did not differ. Ayan et al. (2005) also implied that oriental spruce container seedlings had an intermediate dormancy period in August in the nursery conditions. Thus, it can be stated that their findings and our results supported the summer planting for oriental spruce especially in August. In addition, Ölmez et al. (2010) also reported that summer planting of oriental spruce was suitable for containerized seedlings both in shelter and open field conditions.
The findings from previous studies on summer planting or extending the planting period of some coniferous (Picea abies, Picea engelmannii, Picea glauca, Picea orientalis, Larix decidua, Pinus sylvestris) species which were carried out by Hanak (1987), Revel et al. (1990), Roberts and Long (1991), Malinauskas and Sukhotskas (1996), Helenius et al. (2002), Grossnickle and Folk (2003), Luoranen et al. (2005), Luoranen et al. (2006), Barzdajn (2006) and Ölmez et al. (2010) have supported the results of our research. In Canada, about 5 million 1-year old container seedlings of Picea sitchensis, Picea engelmannii, Picea mariana, Pinus ponderosa, Pinus condorta are produced every year just to be planted in summer. These 1-year old seedlings are usually distributed from the first week of June to the end of September (Anonymous, 2010).

\section{Conclusions}

Overall, it can be said that the planting period can be extended from late July to end of August using actively growing container seedlings of oriental spruce. When the intermediate dormancy period of oriental spruce in the nursery was considered, it is possible to transport and plant seedlings in August with a careful transportation and a successful summer planting. Further investigations in larger reforestation areas are still required using proper seedlings targeted for summer plantings.

\section{References}

Albayrak İH, Hangişi Ölmez G, Çetiner K, Göktürk A (2005). Evaluation of cleaning and culture tending studies in spruce forests of Artvin Reginal Directorate of Forestry. Ladin Symposium, Trabzon 1:360-368 (in Turkish).

Anonymous (1990). Artvin Meteorology Station Data. Artvin Meteoroloji Müdürlüğü, Artvin (in Turkish).

Anonymous (2006). Forest Resources. Çevre ve Orman Bakanliği, Orman Genel Müdürlüğü Yayini, Ankara (in Turkish).

Anonymous (2010). 1 year old seedlings for summer planting. $\mathrm{K}$ and C Silviculture Products and Services, http://www. silviculture.com/product/1+0SuPlant.htm. Accessed 23 February 2010.

Ayan S, Feyzioğlu F, Demircioğlu N, Aksu V (2005). Growth stages of containerized oriental spruce (Picea orientalis L. Link.) seedlings in Of-Trabzon Forest Nursery. Ladin Symposium, Trabzon 1:437-441 (in Turkish).

Barzdajn W (2006). Effect of the production technology and planting date of 1-year old pine (Pinus sylvestris L.) seedlings on the survival and early growt of culture. Sylwan 150(8):3851.

Çepel N (1995). Forest Ecology. 4. Baskı, İstanbul Üniversitesi, Orman Fakültesi, Yayın No:433 (in Turkish).

Eroğlu M, Alkan Akıncı H, Özcan GE (2005). Short and long term control and reform operations against bark beetle 
296

destructions in oriental spruce forests of Turkey. Ladin Symposium, Trabzon 1:184-194 (in Turkish).

Eyüboğlu K, Atasoy H (1984). Studies on Summer Plantings of Picea orientalis. Ormancılık Araştırma Enstitüsü. Teknik Rapor, No: 12.

Grossnickle SC, Folk DS (2003). Spring versus summer spruce stocktypes of Western Canada: Nursery development and field performance. Western J Appl For 18(4):267-275.

Hanak B (1987). Planting time-almost a truism, but is it right? Las Polski 6:12-13.

Helenius P, Luoranen J, Rikala R, Leinonen K (2002). Effect of drought on growth and mortality of actively growing Norway spruce container seedlings planted in summer. Scand J For Res 17(3):218-224.

Helenius P, Luoranen J, Rikala R (2005). Physiological and morphological responses of dormant and growing Norway spruce container seedlings to drought after planting. Ann For Sci 62(3):201-207.

Kiiskila S (2010) Differences in Summer vs. Spring Plant Forest Seedlings. http://www.prt.com/sites/prtgroup/ uploads/1237820433173.pdf. Accessed 23 February 2010.

Luoranen J, Rikala R, Konttinen K, Smolander H (2005). Extending the planting period of dormant and growing Norway spruce container seedlings to early summer. Silva Fennica 39(4):481-496.

Luoranen J, Rikala R, Konttinen K, Smolander H (2006). Summer planting of Picea abies container-grown seedlings: Effects of planting date on survival, height growth and root egress. Forest Ecology and Management 237:534-544.

Malinauskas A, Sukhotskas V (1996). Establishing plantations at different times in the growing season. Lesovedenie 85-88.

Orlic S, Peric S, Ocvirek M (2000). Root-system development of trees in cultures established by summer planting of ballrooted seedlings. Radovi-Sumarski Institut Jastrebarsko $35(2): 17-25$.
Ölmez Z, Süner M, Çetiner K, Hangişi Ölmez G (2010). Effects of summer planting trials on survival rate of oriental spruce (Picea orientalis L. Link.) seedlings. III. Ulusal Karadeniz Ormancilık Kongresi, Artvin 2:839-848 (in Turkish).

Revel J, Lavender DP, Charleson L (1990). Summer Planting of White Spruce and Lodgepole Pine Seedlings. Forestry, FRDA Report 145, Economic and Regional Development Agreement, Canada.

Roberts SD, Long JN (1991). Effects of storage, planting date, and shelter on Engelmann spruce containerized seedlings in the Central Rockies. Western J Appl For 6(2):36-38.

Saatçioğlu F (1970). Artificial Regeneration and Plantation Techniques. Sermet Matbaası, İstanbul (in Turkish).

Sariyildiz T, Akkuzu E, Küçük M, Duman A, Aksu Y (2008). Effects of Ips typographus (L.) damage on litter quality decomposition rates of oriental spruce (Picea orientalis L. Link.) in Hatila Valley National Park, Turkey. Eur J For Res 127:429-440.

Sunar Erbek F, Ölmez Z, Uça Avcı ZD (2005). Using satellite images in surveying insect pest destructions in oriental spruce forests. Ladin Symposium, Trabzon I:222-232 (in Turkish).

Tan W, Blanton S, Bielech JP (2008). Summer planting performance of white spruce $1+0$ container seedlings affected by nursery short-day treatment. New Forests 35:187-205.

Yahyaoğlu Z, Ölmez Z (2006). Afforestation Techniques. Kafkas Üniversitesi Artvin Orman Fakültesi, Yayın No: 2, Artvin (in Turkish). 